\title{
1. Human rights and Islamic legal sources
}

Muslim thinkers and scholars who argue for an Islamic conception of human rights, in general, agree that it is essential for a connection between international human rights and Islamic values to be established if the human rights discourse is to gain widespread support among Muslims. For many Muslims, an Islamic conception of human rights should be based on the authoritative texts of Islam, namely, the Qur'an and the traditions of the Prophet Muhammad (d. 11/632), as well as the principles of Islamic law, as there is a close connection between Muslim discourses on human rights and Islamic law. Therefore, it is important for us to commence our journey exploring Islam and human rights with a brief look at the most important sources of Islamic law and at least some understanding of what Islamic law is. With this in mind, this chapter will first set out the most important Islamic textual sources and legal tools that can be used in this pursuit, briefly recounting some of the history of their development and exploring their potential in developing an Islamic conception of human rights.

\section{THE SOURCES OF ISLAMIC LAW}

\section{The Qur'an}

While Muslims consider the Qur'an to be the Word of God, it is not a legal code. Instead, the Qur' an describes itself as "guidance for humankind" (Q. 2:185). According to Muslim belief, the Qur'an was revealed by God to the Prophet Muhammad over a period stretching from 610 to $632 \mathrm{CE}$, while he lived in Mecca and Medina. These revelations became the foundation for the Prophet's practical and ethical teachings and guidance. Importantly, the particular guidance and teaching that the Qur'an provided to the Prophet and his followers were closely connected to the context of the seventh century CE. Moreover, as the community's situation changed, so did the Qur'an's instructions. 
The society into which the Qur'an was revealed had a different understanding of individual and collective rights to that which exists in many parts of the world today. But despite such differences, I argue that much of the guidance provided in the Qur'an can be applied to our context today. There are only a few verses that are clearly not applicable to the contemporary period. I do not believe that these verses pose an obstacle to the construction of an Islamic human rights discourse. Throughout this book I will highlight some of the verses that appear problematic, as well as those that offer clear pathways towards a conception of human rights that can operate in an Islamic framework.

The most significant such pathway is the Qur'an's insistence on recognising the dignity of the human person. The Qur'an says, "We created human beings in the finest state." (Q. 95:4) The Qur'an also declares that: "We have honoured the children of Adam" (Q 17:70) and, in describing Adam's creation, "I breathed from My Spirit into him." (Q. 38:72) Thus, a unique dignity was granted through God's very act of the creation of Adam, and in particular His breathing into him of His Spirit. Since all of humanity is, according Muslim belief, descended from Adam, every human being possesses this God-given dignity. ${ }^{1}$

In contemporary Muslim scholarship on human rights, it is quite common to find references to these Qur'anic verses, with scholars highlighting the similarities that certain human rights have to the message of the Qur'an. Since God is the primary authority in Islam and the Qur'an is, for Muslims, the very Word of God, to cite the Qur'an in support of a particular human right gives this position great legitimacy. However, this can work both ways. It is equally possible to reject certain rights while drawing on the Qur'an for justification. Qur'anic verses can and have been interpreted towards a variety of ends.

In my view, if the context of any given verse is given proper consideration, the Qur'an can be of great help in developing an Islamic human rights discourse. This is not simply a matter of trying to read certain meanings into relevant Qur'anic texts to support a particular right. Such texts need to be read within the broader framework of the values and norms that the Qur'an contains. It is important to consider how any given text was understood in the early centuries of Islam; how it is understood today; and how this may or may not be applied to contemporary issues. The interpretation of such texts will, of course, vary from period to period, but I agree with Fazlur Rahman that it is always possible to find meaning that remains as a core value, transcending time and place. ${ }^{2}$ It is these core values that can be drawn upon to argue in support of particular human rights within an Islamic framework. 


\section{Hadith or Traditions of the Prophet}

The second important authority in Islam that can be used in developing a meaningful Islamic human rights discourse is the "traditions" of the Prophet, known as the hadith. The hadith are the documentation of the Prophet's example or normative behaviour. An example of hadith relevant to the discourse on human rights are the reports of the Prophet's famous Farewell Sermon, delivered in 10/632:

O People, just as you regard this month, this day, this city as sacred, so regard the life and property of every Muslim as a sacred trust.

Return the goods entrusted to you to their rightful owners. Hurt no one so that no one may hurt you.

O People, it is true that you have certain rights with regard to your women, but they also have rights over you.

Treat your women well and be kind to them, for they are your partners and committed helpers.

All humankind is from Adam and Eve; an Arab has no superiority over a non-Arab and a non-Arab has no superiority over an Arab; a white has no superiority over a black and a black has no superiority over a white, except by piety and good action. ${ }^{3}$

Even though the Prophet lived in the early part of the seventh century CE in Mecca and Medina, his practice and teachings still have relevance to the contemporary period and need to be taken seriously. Given the sheer number of relevant hadith texts and their importance in Islamic legal tradition, it is impossible not to refer to hadith when developing an Islamic conception of human rights based on the practice of the Prophet. Indeed, some Muslim scholars argue that there are a wide range of hadith texts that are extremely relevant to contemporary thinking on human rights. The problem then arises: on what basis can Muslims differentiate between hadith texts that support human rights, and those that may not?

A key issue to be aware of when discussing hadith is that of historical authenticity. While Muslims consider the Qur'anic text to be historically reliable because it was compiled very soon after the Prophet died, the recording of hadith occurred differently. The first generation of Muslims were not particularly keen on putting together a reliable collection of hadith for future generations. This unfortunately resulted in a proliferation of unreliable hadith among the second and third generations of Muslims and beyond. When political conflict was rife among early 
Muslims in the post-prophetic period, hadith were deliberately manipulated and in some cases entirely created in the service of political and ideological ends. Many hadith on the same subject thus may have contradictory messages. Sometimes, understanding the context may help to determine the true message of the hadith in question, but in other cases these contradictions cannot be overcome. Moreover, while the Qur'an quickly became a closed text, the hadith corpus was never a single, fixed document. Rather, they were proliferate and unregulated, and the reports that emerged contained both true prophetic example and inauthentic material.

To address the issue of authenticity, some scholars made it their project to scrutinise the chain of transmission of every hadith in public circulation. Through this analysis, these scholars were able to put together a number of hadith collections that Muslims deemed (to varying degrees) "reliable". Such collections began to emerge in the second century of Islam, continuing into the third and fourth centuries. Eventually, six major hadith collections came to be considered canonical, and remain so today for Sunni Muslims. However, the problem of contradiction continues to exist. Even when referring to the most "authentic" reports, it is still possible to find contradictory material within the hadith sources.

Traditional hadith scholarship relied heavily on the practice of scrutinising the chains of transmission to determine authenticity, but in contemporary Islamic scholarship there is a tendency to question this dependence. Following this view, those hadith that create difficulties for a contemporary human rights discourse might be subjected to further critical analysis. This might include interpreting them in light of their social and historical context, as well as the more traditional scrutiny of their chains of transmission. When a greater awareness of context is reached, it is possible to conclude that some of these hadith are simply no longer applicable in their literal form; alternatively, they might have a deeper message that transcends the literal meaning.

\section{Ijma' (Consensus)}

Apart from its two primary sources-the Qur'an and hadith-Islamic legal tradition deploys other tools that are also relevant here. One of these is ijma' or the consensus of the community (usually understood to be that of the jurists), which is considered a secondary source of law. Like many other issues or concepts within Islam, there are different ways of conceptualising "consensus", and there is no final agreement on what consensus means. However, what is clear is that consensus concerns initial disagreement and diversity of views around a particular issue, and 
then a collectively agreed upon position developing over time. The source of authority on which it appears to be based is Q. 4:59, which states: "You who believe, obey God and the Messenger, and those in authority among you. If you are in dispute over any matter, refer it to God and the Messenger." A hadith attributed to the Prophet also states, "My community will never agree on an error."4

The actual process of consensus therefore involves arriving at a collectively acceptable position after a process of discussion and debate. Such debates may take place over decades or even centuries, but when consensus is achieved, it carries a very high degree of authority. Some examples of consensus that have remained authoritative since the time of the Prophet include the importance of the five daily prayers, the practice of zakat (the obligatory alms tax), and the belief that the Qur'an is revelation from God.

In relation to human rights, Muslim scholars in the past came to a consensus on the idea that in certain cases human beings could be bought and sold. This notion of slavery was accepted in the Islamic legal tradition and was practised by Muslim societies up until the modern period. However, almost all Muslim scholars now argue that this consensus does not have any authority today. In fact, slavery in the sense of buying and selling human beings was abolished in all Muslim societies, where it was practised, in the twentieth century. This means that even though there may have been consensus on certain issues in the past, such consensus can be challenged in the modern period because of the significant differences between the context of the modern period and of the past.

\section{Qiyas (Analogical Reasoning)}

The final tool that is used to derive Islamic law is analogy or qiyas. Analogical reasoning has always been important in Islamic legal tradition. In fact, a large number of rules that are part of what we call Islamic law today were actually developed using analogy, based on the Qur'an and hadith. Given that there are very few texts in the Qur'an that are specifically related to matters of law, and the limitations in using hadith (discussed above), qiyas was regularly deployed to expand and apply what was textually available to a wider range of situations and circumstances..$^{5}$ As an example, Q. 2:219 clearly prohibits the consumption of wine. The rationale behind this prohibition, according to many jurists, is the effect of alcohol on the mind. Based on this rationale, any product that produces the same effects, such as narcotics, can be considered prohibited by analogy, thus expanding the scope of the rule. ${ }^{6}$ 
Without analogical reasoning, Islamic law as we know it probably would not have developed. It is because of analogy that we have such a comprehensive system of rules, regulations and laws in classical Islamic legal sources for addressing most aspects of life. However as people living in the twenty-first century, we may not necessarily agree with all the precepts that Muslim jurists developed during the early period of Islam. The twenty-first century is a very different time compared to the pre-modern period, and thus calls for different understandings, particularly in the area of rights. This is where analogical reasoning is crucial today: it is possible to use analogy to broaden our understanding of an Islamic conception of human rights and to develop new ideas or positions in relation to particular human rights.

\section{THE SHARI'A OR ISLAMIC LAW}

I will now turn to an overview of the development of Islamic law-the Shari'a-with particular emphasis on the features of that development which lend themselves to the modern discourse on human rights.

\section{Meaning and Historical Development}

'Shari'a' is the term usually associated with the idea of "Islamic law". The term occurs once in the Qur'an, where it designates a divinely appointed path: "Now we have set you on a clear religious path (shari'a), so follow it." (Q. 45:18) The term is linguistically associated with notions of "the way" or "the road". From this, the Shari'a is considered to be the path set out by God for Muslims to follow in order to achieve salvation. It refers to the totality of the guidance contained in the Qur'an and Sunna (the normative example of Prophet Muhammad).

Although Shari'a is the term most commonly associated with Islamic law, it is important to distinguish between Shari'a and figh. The word fiqh originally meant "understanding" or "discernment" in a general sense, and it occurs in the Qur'an and hadith with that meaning. ${ }^{7}$ With the development of separate disciplines of law, theology, and asceticism in the second/eighth and third/ninth centuries, fiqh came to refer only to legal knowledge. Gradually, Shari'a and fiqh also came to be differentiated. "Shari'a" came to refer to the totality of God's law in its perfect state, whereas "fiqh" referred to specific rulings obtained by interpreting the primary texts of the Qur'an and hadith using the tools referred to above. ${ }^{8}$ Thus, for Muslims, while the source of the Shari'a is God, fiqh comes from human effort. Despite these differences, in the modern 
period (and also throughout this book), "Islamic law" and "Shari' a" are often used synonymously.

It is important to emphasise that Shari'a or "Islamic law" is not a unified body of law. Within it there are many schools of legal thought and, on any particular legal or moral issue, there may be a wide range of divergent views. On the one hand, this makes the task of determining whether human rights norms and Islamic law can be reconciled more difficult; on the other, it also allows considerable scope for finding compatibilities.

\section{The Historical Development of the Shari'a: Four Key Stages}

As I have written elsewhere, ${ }^{9}$ the early development of the Shari'a (or Islamic law) can be divided into four stages. The first stage was the period when the Qur'an was revealed. At this time the Qur'an set down laws related to the individual (such as prayers and fasting) and for society more broadly (such as marriage, commercial transactions, and criminal law). All of these laws reoriented society towards a new, universal set of norms

that transcended the previous pre-Islamic focus on kinship and tribal allegiance. ${ }^{10}$

The laws of the Qur'an were not arbitrary - they aimed to realise certain ideals. These included the creation of a just and compassionate society, as well as instilling personal morality and God-consciousness. ${ }^{11}$ By "laws" I refer both to specific rulings as well as more general principles and values. The Qur'an often prescribes conduct but is silent on the details, such as for the prayer and the zakat alms-tax. ${ }^{12}$

The second stage occurred after the Prophet's death. Islamic law was being developed by the Prophet's Companions utilising ijtihad (individual reasoning). Islam was spreading outside Arabia and coming into contact with other cultures. The Muslim community had to "navigate an uncharted path for which the Qur'an provided little guidance". 13

The Companions were able to guide the Muslim community in situations where the Qur'an or the Sunna did not provide a specific answer. Alongside the development and use of ijtihad, a type of consultation also existed in the development of law, especially during the time of the first four caliphs, known among Sunni Muslims as "Rightly Guided". Historical reports point to the existence of a consultative body that could debate points of law and enact new rulings at the time.

The third stage begins with the time of the Successors (the second generation of Muslims), which spanned roughly the Umayyad caliphate from 41/661 to $132 / 750$, up to the early years of the Abbasid caliphate. At this time, some changes took place which affected the trajectory of 
Islamic legal development. The Umayyads instituted dynastic rule and ended the form of consultation which had existed under the Rashidun (Rightly Guided) caliphs. Also, "law" was increasingly being developed by individual jurists in various key regions of the expanding Muslim caliphate. These jurists continued to practise ijtihad, and their efforts and creativity had a significant impact on the form and content of Islamic law. Their debates, teaching, and opinions are considered part of the raw material for Islamic law.

During this period, the practice of the Prophet and the Companions began to be emphasised as a fundamental source of law. In addition, two distinct approaches towards law and legal theory began to emerge: that of the "people of reason/opinion", often called "rationalists", and that of the "people of hadith", or "traditionists". ${ }^{14}$ While the former emphasised the importance of reason, without neglecting the texts, the latter tended to base their opinions largely on texts (specifically, the Qur'an and hadith). ${ }^{15}$ These two approaches struggled for hermeneutic primacy. This struggle was exemplified in the Mihna (inquisition), from 218/833 until 234/848. ${ }^{16}$ The Mihna was a critical struggle between the traditionists (led by the hadith scholar Ahmad b. Hanbal (d. 241/855)) and the rationalists (led by a group of rationalist theologians, known as Mu'tazilis, and some Abbasid caliphs). Debate over the status of the Qur'an and whether it was "created" or not led to a much broader debate on the place of human reason in the interpretation of the divinely revealed texts and, by extension, the role of reason in deducing the law. This intellectual struggle ebbed and flowed throughout the early history of Islam, until the fourth/tenth century saw what Wael Hallaq has termed "the great synthesis". This was in essence a compromise between traditionism and rationalism: "It was the midpoint between the two movements that constituted the normative position of the majority; and it was from this centrist position that Sunnism, the religious and legal ideology of the majority of Muslims, was to emerge". ${ }^{17}$

The combining of the two dominant approaches culminated in the idea "that human reasoning must play a significant role in the law, but can in no way transcend the dictates of revelation". ${ }^{18}$

The final stage of the early development of Islamic law can be described as the rise of the jurists. The evolution of their authority meant that the jurists formed a separate source of legal authority to the caliph, creating a kind of separation of powers. As Hallaq explains:

Those men in possession of a greater store of knowledge grew more influential than others less learned, gaining in the process-by the sheer 
virtuousness of their knowledge-an authority that began to challenge the legal (but not political) authority of the caliphs. ${ }^{19}$

This period began around 150/767 and continued into the third/ninth century. At that time, the major schools of law (the Sunni schools, Hanafi, Maliki, Shafi'i, and Hanbali, and the Shi'i Ja'fari school) began to emerge. Once established, these schools began to exercise great authority over the interpretation and application of Islamic law, and the view eventually emerged that somehow the venerated founders of the schools had completed all the necessary tasks of legal analysis and defined all the major intellectual structures of the law. As a result, new ways of looking at the text and constructing or interpreting law were discouraged to some extent in favour of faithfully following what these earlier scholars had done.

\section{ISLAMIC LEGAL CONCEPTS AND STRATEGIES TO ENGAGE WITH INTERNATIONAL HUMAN RIGHTS NORMS}

Since Shari'a (or Islamic law) forms such a central part of Muslim discourses on human rights today, it is important to identify resources from within this tradition that can be used to engage with international human rights norms. There are many concepts and tools that could be used for this purpose, but in this chapter I will identify those that I believe are the most important in this endeavour. In the second half of the book I will explore how Muslim thinkers and scholars are using such resources to harmonise international human rights law and Islamic law.

\section{Human Rights as Binding by Agreement}

It is possible to conceive of human rights norms as arising out of international law, and thus binding on all states by agreement. This way of thinking about human rights does not require us to subscribe to particular philosophical justifications, but sees them as an important part of the current legal and political landscape. Muslim-majority states function within a framework of international law and relations that have been established by the international community. Although it is theoretically possible for states to disconnect or isolate themselves from other states, in practice this would be extremely costly politically and economically, to say the least. An important tenet of Islamic law is the requirement to honour one's agreements. All Muslim-majority countries 
are member states of the United Nations, and a number of important Muslim jurists have stated the view that the United Nations Charter represents a binding international agreement for Muslim States. In addition, since at least the 1980s, human rights language has been incorporated into trade agreements by major powers such as the United States and European Union. ${ }^{20}$ Today, most important trading countries sometimes include human rights provisions in their preferential trade agreements. Some of these are binding. ${ }^{21}$ Thus Muslim-majority states must function and interact within a global environment where human rights are strongly valued and considered an important part of the international legal and political framework.

\section{Taking into Consideration the Principle of Darura (Necessity)}

A key principle that is highly relevant is that of necessity (darura). This Islamic legal concept allows Muslims to depart from an established legal ruling in exceptional circumstances, as long as the result does not go against the fundamental objectives of the Shari'a. The principle of darura can be invoked in a situation where applying the original legal ruling may result in loss or damage to one of the "five fundamentals": protection of a person's religion, life, lineage, reason, or property. ${ }^{22}$ In such cases, this legal concept of necessity can be used to remove the hardship or risk to the person. ${ }^{23}$

A related concept is "need" (haja). Haja is defined in Islamic jurisprudence as "those things which put the Muslim in a difficulty, if not fulfilled, even if he/she can do without". ${ }^{24}$ The concept of haja therefore allows the removal of a difficulty that is causing a person hardship. ${ }^{25}$ Haja is different from darura because with haja a person's life is not threatened or in danger from the impediment (nor are any of the five fundamentals at stake); however, without removing the difficulty, the person will face significant hardship. ${ }^{26}$ When a haja affects a whole society, the need becomes a "universal need" (haja 'amma). ${ }^{27}$ When it becomes such a universal need, then it becomes very similar to necessity.

Both of these concepts are very useful for helping Muslims respond to the international human rights discourse today. Where difficulties or tensions arise in the areas of certain rights, the concepts of necessity and need can be used as a justification for modifying certain traditional legal rulings because of compelling circumstances. 


\section{Reliance on Hikma (Rationale and Wisdom)}

Another way to address difficulties between Islamic law and international human rights law is to apply the concept of hikma, where the rationale and wisdom behind a Qur'anic or prophetic prescription is taken into account. For instance, as discussed further in Chapter 7, many scholars argue that the rationale behind the Qur'an allowing the practice of polygyny was to ensure justice and protection for vulnerable members of the Muslim community; namely widows and orphans. If Q. 4:3, the verse that sanctions polygyny, is taken literally, without any deeper understanding, it stands in tension with those provisions of human rights law that affirm equality between men and women, particularly in the context of marriage. However, by taking into account the hikma of the verse, the apparent difficulties can be resolved to some extent.

\section{Contextualisation of Relevant Texts}

One approach that is useful for addressing tensions between Islamic law and international human rights law is to contextualise, where feasible, those verses of the Qur'an or traditions of the Prophet (hadith) that appear to conflict with international human rights standards. By contextualising these texts, scholars may consider a text's original purpose, and how this might be applied in today's context.

However, it is important to keep in mind that contextualising a text is not simply a matter of reading into the text a predetermined meaning. Rather, it is a principled approach that not only takes the linguistic meaning of the text seriously but goes further, and gives consideration to the original context in which the Qur' anic revelation occurred in the early seventh century CE. This includes its political, social, economic, intellectual, and religious context, and the values, norms, and institutions that existed in that society and have a bearing on the particular issue being explored. Through analysis, the interpreter can determine how the text was understood among the first generation of Muslims and in the early periods of Islamic history, as well as within the context of that time.

Once this has been determined, the interpreter will then relate this understanding to the present context. This involves analysing all the relevant aspects of the contemporary context, including its social, political, cultural, economic or intellectual elements, and comparing and contrasting this to the original context of the text. This process will lead to a relevant interpretation of the text, without sacrificing its ultimate objective and fundamental message. Consideration also needs to be given 
to the concerns and needs of the time; common sense; the sensibilities of the broader religious community; and the fundamental values and practices that the Qur'an and Prophet Muhammad emphasised.

\section{Keeping an Eye on the Mutable and Immutable}

When contextualising texts of the Qur'an or hadith that are associated with human rights, Muslim scholars often discuss whether a particular ruling or decision associated with a text is changeable or unchangeable (or, in other words, mutable or immutable). Many Muslims would argue that if a ruling is considered so important or fundamental to Islamic law it should not be modified or changed in light of international human rights law and, in such cases, Muslim scholars should not give in to demands made by the international human rights community. While Muslim scholars have explored the idea of mutable and immutable in Islamic law for many centuries, using different terminology and language, it still remains an important concern for Muslims today when engaging with international human rights norms.

Although there is no universally agreed upon definition of what is considered mutable or immutable, it is possible to list categories of rulings that Muslims, in general, consider to be immutable. For example, the fundamental beliefs of Muslims: belief in one God, the prophets, the Scriptures and life after death; the fundamental pillars of Islam: the five daily prayers, fasting, zakat and pilgrimage; and those matters that are clearly made permissible or prohibited in the Qur'an or traditions of the Prophet, such as theft (prohibited) or buying and selling (permitted). These are all considered immutable, and the belief is that no Muslim has the authority to go against them. Beyond this, there may also be other immutables, although they may not have the broad universal agreement that these kinds of fundamentals enjoy.

In the area of human rights, most of the difficulties Muslims experience are not about such universally agreed upon immutables, but about legal rulings where there is less agreement. These rulings often come from a particular scholar's independent reasoning (ijtihad) or may even be the standard position of a particular school of law. In such cases there is room to check whether the ruling is in fact a universally agreed upon immutable or not. For example, in the case of gender equality, there is no universally agreed upon position among Muslims that opposing (or supporting) gender equality is a fundamental value in Islam. Similarly, in the case of Muslim men being able to marry more than one woman, there is no universally agreed upon position which suggests that this is something Muslim men must do. Thus, there is room for Muslim scholars 
to explore whether such rulings can be rethought in light of our contemporary context and brought in line with contemporary human rights concerns and standards. This gives Muslim scholars significant flexibility to creatively engage with international human rights law; contribute new ideas to this engagement; and to perhaps develop relevant new 'Islamic' understandings.

The issue of immutability is particularly important when we examine the engagement of Muslim-majority states with the international human rights treaty regime. The vast majority of states' objections to particular rights, which can be seen in the reservations made against various articles of the treaties, are by and large not related to immutable issues, as we will see in Chapters 7 to 11 .

\section{CONCLUSION}

This chapter has provided a brief overview of the most important sources of Islamic law for any discussion on Islam and human rights today. In developing arguments in favour of human rights or even against human rights, Muslims have relied on these sources as well as methods of interpretation that have been developed over many centuries. While texts can be read in very different ways, what is important is to highlight that within Islamic tradition, there are a large number of texts, ideas, views and interpretations, as well as principles and strategies that provide room for exploring and perhaps even rethinking some of the legal rulings that may have relevance to the kind of concerns articulated in this book. As I will argue, these can be used successfully to develop an Islamic understanding of human rights that is not in conflict with internationally accepted standards and norms. An understanding of these views, principles and strategies is extremely important for engaging successfully in the discourse on Islam and human rights.

$$
* * *
$$

\section{LOOKING AT AN ISSUE CLOSELY: THE CASE OF "RIGHTS" IN THE HADITH}

The second most important textual authority in Islam after the Qur'an is the collected traditions of the Prophet, known as hadith. Below a number of hadith that support the notion of rights in general or specific substantive rights. In any attempt to provide an Islamic conception of 
human rights that may form a basis for reconciliation with international human rights law, it is often important to cite the necessary texts from the Qur'an and the traditions of the Prophet. As we can see below, there are resources in these traditions that can be helpful when developing Islamic arguments in favour of human rights.

- One of the Companions of the Prophet, Salman said: "Your Lord has a right over you; and your soul has a right over you; and your family has a right over you; so you should give all those who have a right over you their rights." The Prophet said, "Salman has spoken the truth." 28

- The Prophet said: "Whoever has oppressed another person concerning his reputation or anything else, he should beg him to forgive him before the Day of Resurrection when there will be no money [to compensate for wrong deeds]; if he has good deeds, those good deeds will be taken from him according to the oppression he has committed, and if he has no good deeds, the sins of the oppressed person will be loaded onto him." 29

- The Prophet said: "On the Day of Judgment, [all] rights will be given to those to whom they are due." ${ }^{30}$

- When a funeral procession passed by the Prophet, and he stood up, it was said to him, "It is a Jew." The Prophet said, "Was he not a soul?"31

- The Prophet said, "Certainly, I witnessed a pact [of justice] in the house of Abd Allah b. Jud'an which, if I were called to it now in the time of Islam, I would respond. Make such alliances in order to return rights to their people, that no oppressor should have power over the oppressed." 32 This hadith is regarding the Hilf al-Fudul [Pact of the Virtuous], a pact of justice made by the people of Mecca, including the young Prophet Muhammad, in which they pledged to respect the principles of justice and intervene to support the oppressed, no matter what their tribal affiliation.

- The Prophet said: "Five are the rights of a Muslim over his brother: returning the greeting of peace; visiting the sick; following the funeral processions; accepting invitations; and saying "God have mercy on you" when someone sneezes. ${ }^{33}$

- The Prophet said during his Farewell Sermon: "Verily, your blood, your property and your honour are sacred to one another, like the sanctity of this day of yours, in this month of yours and in this city of yours." ${ }^{34}$ 
- The Prophet said: "Guard [the right of] the two weak ones: the slave and the woman." 35

- The Prophet said, "He is not from my nation who does not honour our elders, nor have mercy on our young ones, nor recognize the rights of our scholars." 36

Apart from the traditions of the Prophet, there are also views expressed by Muslim jurists on issues that are relevant to the human rights discourse today. Below I provide two such views:

- Abu Bakr al-Sarakhsi (d. 483/1090), a leading Hanafi jurist of the eleventh century CE, said: "When God the Exalted created humanity to carry His Trust (amana), He dignified them with reason ('aql) and sacred inviolability (dhimma) in order to be responsible for fulfilling the rights (huquq) of God placed over them. Then $\mathrm{He}$ granted them sanctity ('isma), freedom (hurriyya), and property rights, so that they might endure, and be able to carry out the Trust. Hence, this freedom, sanctity, and right of property are established [as a property] of a person at the time they are born. Those capable of discernment (mumayyiz) and those who are not are equal in this regard, and likewise sacred inviolability is established at birth whether they are of sound mind or not."37

- Muhammad al-Shaybani (d. 189/805), an eminent early Hanafi jurist, said: "The basic principle $(a s l)$ is that it is an obligation upon the leader of the Muslims to support those who reside in our country under a covenant of protection (al-musta'manun). They must be given recourse against anyone who oppresses them, just as it is an obligation to fulfil the rights of non-Muslim citizens." 38

\section{NOTES}

1. See Abdullah al-Ahsan, "Law, Religion and Human Dignity in the Muslim World Today: An Examination of OIC's Cairo Declaration of Human Rights", Journal of Law and Religion 24(2) (2008-09): 569.

2. See Fazlur Rahman, Islam and Modernity: Transformation of an Intellectual Tradition (Chicago: University of Chicago Press, 1984), 6-7.

3. The Prophet Muhammad, "Prophet Muhammad's Last Sermon" (Islam The Modern Religion). Available http://www.themodernreligion.com/prophet/prophet-lastsermon.htm (last accessed 4 December 2017).

4. Ibn Majah, Sunan Ibn Majah, Kitab al-fitan, bab al-sawad al-a'ẓam, No. 3950; Tirmidhi, Jami' al-Tirmidhi, Kitab al-fitan, No. 2167.

5. Abdullah Saeed, Islamic Thought: An Introduction (Abingdon, UK: Routledge, 2006), 49.

6. Saeed, Islamic Thought, 49.

7. See Q. 7:179. 
8. Saeed, Islamic Thought, 44.

9. Ibid, 46-7.

10. See Wael B. Hallaq, The Origins and Evolution of Islamic Law (Cambridge: Cambridge University Press, 2005), 22.

11. Saeed, Islamic Thought, 46.

12. Ibid.

13. Hallaq, Origins, 33.

14. Saeed, Islamic Thought, 47.

15. Ibid.

16. Hallaq, Origins, 124.

17. Ibid 125 .

18. Ibid 148 .

19. Ibid 77.

20. Susan Ariel Aaronson and Jean Pierre Chauffour, "The Wedding of Trade and Human Rights: Marriage of Convenience or Permanent Match?" (2011) WTO 15 February 2011. Available https://www.wto.org/english/res_e/publications_e/wtr11_forum_e/wtr11_15feb11 _e.htm\#feedback (last accessed 28 November 2017).

21. Ibid.

22. Mansour Z. Al-Mutairi, "Necessity in Islamic Law" (1997). Thesis submitted to the University of Edinburgh for the Degree of Doctor of Philosophy. January 1997, 171-2.

23. Ibid.

24. European Council for Fatwa and Research's Resolution on "Permissibility of Conventional Mortgage under Necessity". Fourth Ordinary Session [27-31 October, 1999]. Available http://eshaykh.com/halal_haram/permissibility-of-conventional-mortgage-under-necessity (last accessed 4 December 2017).

25. Al-Mutairi, "Necessity in Islamic Law", 17.

26. Ibid 66 .

27. Rationale for the Fatwa on Mortgage (2001), 4.

28. Al-Bukhari, Sahih al-Bukhari, Kitab al-sawm, No. 1968.

29. Al-Bukhari, Sahih al-Bukhari, Kitab al-mazalim, No. 2449.

30. Muslim, Sahih Muslim, Kitab al-birr wa-1-sila wa-l-adab, No. 2582.

31. Al-Bukhari, Sahih al-Bukhari, Kitab al-jana'iz, Nos. 1312-13; Muslim, Sahih Muslim, Kitab al-jana'iz, No. 961.

32. Abu Muhammad Qasim b. Thabit al-Saraqusti, al-Dala'il fi gharib al-hadith, ed. Muhammad al-Qannas (Riyadh: Maktabat al-Ubaykan, 1421), 2:487, No. 265; Abu Bakr al-Bayhaqi, al-Sunan al-Kubra, ed. Muhammad Ata (Beirut: Dar al-Kutub al-Ilmiyya, 1424/2003), 6:596, Kitab al-wasaya, No. 13080.

33. Al-Bukhari, Sahih al-Bukhari, Kitab al-jana'iz, No. 1240.

34. Al-Bukhari, Sahih al-Bukhari, Kitab al-hajj, No. 1739; idem, Kitab al-hudud, No. 6785; Muslim, Sahih Muslim, Kitab al-qasama, No. 1679.

35. Abu al-Qasim b. Asakir, Tarikh Madinat Dimashq, ed. Amr al-Amrawi (Cairo: Dar al-Fikr, 1415/1995), 52:38, No. 6086. In another narration, the Prophet said: "Fear God [regarding the rights of] the two weak ones: the orphan and the woman." Abu Ja'far al-Tabari, Jami' al-bayan an tafsir ay al-Qur'an, ed. Ahmad Shakir (Beirut: Mu'assasat al-Risala, 1420/2000), 7:561, sub Q. 4:5.

36. Ahmad b. Hanbal, Musnad, eds, Shu'ayb al-Arna'ut and Adil Murshid et al. (Beirut: Mu'assasat al-Risala, 1421/2001), 37:416, Hadith Ubada b. al-Samit, No. 22755.

37. Abu Bakr al-Sarakhsi, Kitab al-Usul (Beirut: Dar al-Ma'rifa, n.d.), 2:334, Fasl fi bayan taqsim al-alama.

38. Abu Bakr al-Sarakhsi, Sharh al-siyar al-kabir, (n.p.: al-Sharika al-Sharqiyya li-l-I'lanat, 1971), 1853, Bab ma yajib min al-nusra li-l-musta'manin wa-ahl al-dhimma. 